\title{
Early diagnosis of acute myocardial infarction
}

\author{
Electrocardiography is still best
}

Acute myocardial infarction is usually caused by thrombotic occlusion of a coronary artery. The left ventri ular subendocardium infarcts within 30 minutes, but extension to affect the full thickness of the ventricular wall may take several hours.' The size of the infarct depends largely on the distribution of the occluded artery, although collateral vessels or spontaneous recanalisation may limit it to the subendocardial layer. ${ }^{1-3}$ Thrombolytic treatment also limits the size of the infarct if coronary recanalisation occurs before the transmural spread of infarction is complete. ${ }^{+5}$ This reduces mortality in patients treated within 24 hours after the onset of symptoms, although the benefit is greater the earlier treatment is given. ${ }^{67}$ Early diagnosis is therefore important.

Electrocardiography provides the most convenient and reliable method of early diagnosis in patients with chest pain. Experience with angioplasty has shown that electrocardiographic changes occur within seconds after coronary occlusion, ${ }^{89}$ and over four fifths of patients with acute infarction already have an abnormal recording at presentation. ${ }^{10}$ " Regional ST elevation is the typical abnormality and predicts acute infarction with almost $100 \%$ accuracy, only a few patients with pericarditis or old $Q$ wave infarction causing diagnostic difficulty. ${ }^{12} 13$ Over a fifth of patients with suspected infarction, however, present with isolated ST depression or $\mathrm{T}$ wave inversion, and occasionally the electrocardiogram is normal. ${ }^{13}$ These findings are only weakly predictive of infarction and confirmation must await additional tests.

One of the earliest histological manifestations of myocardial infarction is disruption of the sarcolemmal membrane. ${ }^{1+15}$ Disruption allows the intracellular proteins to escape into the circulation for use as biochemical markers of infarction. Creatine kinase and its more specific MB isoenzyme are the most widely used, but blood activities do not rise above normal until 6-10 hours after the onset of symptoms. ${ }^{16}$ Enzyme subform analysis has shown an increase in the ratio of myocardial creatine kinase MM3 to its metabolite creatine kinase MM1 within six hours, but this analysis is not widely available and the finding may be too non-specific for early diagnosis. ${ }^{1718}$ Myoglobin diffuses rapidly out of injured cardiac myocytes, causing a rise in blood concentrations within one and a half hours in some patients. ${ }^{19}$ Until recently the myoglobin assay was too laborious for routine use, but a more rapid latex agglutination assay is now available and has been recommended when the presenting electrocardiogram is equivocal. ${ }^{20}$ Not all investigators have found the assay reliable, however, ${ }^{2122}$ and it has been difficult to show a substantial advantage for myoglobin over creatine kinase $M B$, single measurements rarely being diagnostic in the first 12 hours. ${ }^{23-25}$

Non-invasive imaging provides an alternative diagnostic approach in acute myocardial infarction, although the need for expensive equipment limits its application. Echocardiography reliably identifies abnormalities of wall motion soon after coronary occlusion ${ }^{8}$ but fails to distinguish between acute infarction, old infarction, and unstable angina. Myocardial scintigraphy with infarct avid agents (usually technetium-99 pyrophosphate) is also of limited value because the uptake of the isotope is rarely adequate for imaging until 12-24 hours after the onset of symptoms. The role of immunoscintigraphy with antimyosin antibody fragments is being investigated. These fragments adhere to myosin filaments through sarcolemmal defects in necrotic cells and in animal studies have detected infarction very early after interruption of coronary flow. ${ }^{26}$ Clinically, however, this technique is less helpful because cardiac scintigraphy cannot be done until 24 hours after administration of the antibody to permit its clearance from the blood. ${ }^{28}$

At present, therefore, the early diagnosis of acute myocardial infarction must be based on electrocardiographic criteria, and patients with chest pain and regional ST elevation should receive thrombolytic treatment without delay. Whether treatment should await the results of additional tests in patients without ST elevation has been questioned by two large studies in which inclusion was based on clinical suspicion of infarction regardless of electrocardiographic findings. ${ }^{729}$ Both showed significant reductions in early mortality in patients randomised to thrombolytic treatment, suggesting that clinical suspicion may indeed be a reasonable guide to treatment. Nevertheless, because electrocardiographic findings were not among the inclusion criteria, neither study confirmed that thrombolytic treatment is beneficial in patients without ST elevation. Only about half of these patients will have an infarct $(20 \%$ if the electrocardiogram is normal), and mortality is low. ${ }^{1012} 13$ Thus the risks and benefits of treatment will be more finely balanced unless an additional diagnostic test can be applied. The test must be available 24 hours a day, be rapidly interpretable, and be diagnostic very early after the onset of symptoms. Because none of the available biochemical or imaging methods fully meets these criteria electrocardiography remains the cornerstone of early diagnosis.

At Newham patients with regional ST elevation presenting 
within 24 hours after the onset of continuous chest pain are given thrombolytic treatment. Patients with ST depression or deep $\mathrm{T}$ wave inversion are at first treated for unstable angina with heparin, aspirin, nitrates, and $\beta$ blockers. If chest pain persists after two hours and electrocardiographic changes show no tendency to resolve myocardial infarction is assumed and streptokinase infusion started. Early resolution of electrocardiographic changes, on the other hand, is taken to indicate reversible ischaemia requiring no additional treatment. No patient with a normal electrocardiogram receives thrombolytic treatment.

Consultant Cardiologist, Newham General Hospital,

ADAM D TIMMIS

London E13 8RU

1 Reimer KA, Jennings RB. The "wavefront phenomenon" of myocardial ischemic cell death. 2 Transmural progression of necrosis within the framework of ischemic bed size mvocardium at Transmural progression of necrosis within the fram
risk) and collateral flow. Lab Invest 1979;40:633-44.

2 Huey BL, Gheorghiade $M$, Crampton RS, et al. Acute non- $\mathrm{Q}$ wave myocardial infarction associated with early ST segment elevation: evidence for spontaneous coronary reperfusion and implications for thrombolytic trials. $7 \mathrm{Am}$ Coll Cardiol 1987;9:18-25.

3 Timmis AD, Griffin B, Crick JCP, Nelson DJ, Sowton E. The effects of early coronary patency on the evolution of myocardial infarction: a prospective arteriographic study. Br Hearl $f$ 1987;58:345-51.

4 Simoons ML, Serruys PW, Van den Brand M, et al. Early thrombolysis in acute myocardial infarction: limitation of infarct size and improved survival. $\mathcal{f}$. $m$ Coll Cardiol 1986;7:729-42.

5 White HD, Norris RM, Brown MA, et al. Effect of intravenous streptokinase on left ventricular function and early survival after acute myocardial infarction. $N$ Engl f Med 1987;317:850-5.

6 Gruppo Italiano per to Studio della Streptochinasi nell'Infarcto Miocardico. Effectiveness of intravenous thrombolytic treatment in acute myocardial infarction. Lancel 1986;i:397-402.

7 Second International Study of Infarct Survival. Randomised trial of intravenous streptokinase, oral aspirin, both, or neither among 17,187 cases of suspected myocardial infarction. Lancet
1988 ;ii:349-60.

8 Griffin B, Timmis AD, Crick JCP, Sowton E. The evolution of mrocardial ischaemia during percutaneous transluminal coronary angioplastv. Eur Heart 7 1987:8:347-53.

9 Norell MS, Lyons JP, Gershlick AH, et al. Assessment of teft ventricular performance during coronary angioplasty: a study of intravenous digital subtraction ventriculography. Br Heart $\mathcal{F}$ 1988;59:419-28.
10 Brush JF, Brand DA, Acamposa D, Chalmer B, Wackers FJ. Use of the electrocardiogram to predict in-hospital complications of acute myocardial infarction. $N$ Engl f Med 1985;312. $1137+1$

11 Lee TH, Rouan GW, Weisherg MC, et al. Sensitivity of routine clinical criteria for diagnosing myocardial infarction within 24 hours of hospitalization. Ann Intern. Med 1987;106:181-6.

12 Ruse RE, Poole K, Muller JE, et al. Electrocardiographic and clinical criteria for recognition of acute myocardial infarction based on the analysis of 3,697 patients. A $m$ f Cardiol 1983;52:936-42.

13 Yusuf S, Pearson M. Sterry H, et al. The entry ECG in the carly diagnosis and prognostic stratification of patients with suspected acute myocardial infarction. Eur Heart 7 1984;5:716-26. 4 Ashraf M, Sybers HD. Scanning electron microscopy of the heart after coronary occlusion. Lab Invest 1975;32:157-62

15 Jennings RB, Baum $\mathrm{JH}$, Herdson $\mathrm{PB}$. Fine structural changes in myocardial ischemic injury. Arch Pathol 1965;79:135-43.

16 Lee TH, Goldman L. Serum enzyme assays in the diagnosis of acute myocardial infarction recommendations based on a quantitative analysis. Ann Intern .Med 1986;105:221-33.

$17 \mathrm{Jaffe}$ AS, Serota H, Grace A, et al. Diagnostic changes in plasma creatine kinase isoforms early after the onset of acute myocardial infarction. Circulation 1986;74:105-9.

18 Morelli RI., Carlson CJ, Emilson B, et al. Serum creatine kinase MM isoenzyme sub-bands after acute mvocardial infarction in man. Circulation 1983:67:1283-9.

19 Granadier $\mathrm{F}$, Keider S. Kahana L, et al. The roles of serum myoglobin, total CPK, and CK-MB isoenzyme in the acute phase of myocardial infarction. Am Heart $f$ 1983;105:408-14.

20 Ohman EM, Casey C, Bengtson JR, Pryor D, Tormey W, Horgan JH. Early detection of acute myocardial infarction: additional diagnostic information from serum concentrations of myoglobin in patients without ST elevation. Br Heart f 1990;63:335-8.

21 Hangaard J, Rasmussen $O$, Norregaard-Hansen K, Jorgensen N, Simonsen EE, Norregaard Hansen B. Early diagnosis of acute myocardial infarction with a rapid latex agglutination test for semi-quantitative estimation of serum myoglobin. Acta Med Scand 1987;221:343-8.

2 Fitzgerald RJ, Tormey WP. A rapid slide agglutination test contrasted with a radioimmuoassay for myoglohin measurement for early diagnosis of myocardial necrosis. Ir f. Med Sci 1988;157:293-4.

23 Freeman AP, Fatches KR, Carter IW, Cloonan MJ, Wilcken DEL. Comparison of serum myoglobin and creatine kinase $\mathrm{MB}$ isoenzyme in early diagnosis of acute myocardial infarction BrHearl f 1981:45:389-92.

24 Collinson PO, Rosalki SB, Flather M, Wolman R, Evans T. Early diagnosis of myocardial infarction br timed sequential enzrme measurements. Ann Clin Biochem 1988:25:376-82.

25 Kallner A, Svlven C. Brodin L, Loogna E, Svenham K. Early diagnosis of acute myocardial infarction. A comparison between chemical predictors. Scand f Clin Lab Invest 1989:49:633-9.

26 Khaw BA, Beller GA, Haber F, Smith TW. Localization of cardiac myosin-specific antibody in myocardial infarction. F Clin Invest 1976;58:439-46.

27 Timmis AI), Lopez JA, Falon JT, Khaw BA, Haber E, Powell WJ. Detection of early necrosis in a canine model of low flow myocardial ischemia using "I-antimyson $(\mathrm{FAB})_{2}$. Fournal of Applied Cardiology 1987;2:185-211.

28 Jain D, Lahiri A, Raftery EB. Immunoscintigraphy for detecting acute myocardial infarction without electrocardiographic changes. Br Med 7 1990;300:151-3.

29 Wilcox RG, Von der Lippe G, Olsson CG, Jensen G, Skene AM, Hampton JR. Trial of tissuc plasminogen activator for mortality reduction in acute myocardial infarction: Anglo-Scandinavian study of early thrombolysis (ASSET). Lancet 1988;ii:525-30.

\section{Flat feet in children}

\section{Accurate diagnosis is the key}

Problems with children's feet illustrate several important general principles: that there is a wide range of normal in the developing child; that variations in shape are often transient and will correct with growth; that "flat feet" describes a deformity and is not necessarily a diagnosis; and that symptoms from the feet may indicate a more proximal disorder.

The shape of the foot depends on normal tarsal bones, normal articulation and ligamentous support between the tarsal bones, normal neuromuscular function, and, finally, a normal weight distribution from above - that is, a normally aligned leg. This is a lot of normals, each of which may be late to develop, and apparent foot abnormalities such as flat feet may occur at any time during growth.

At birth most infants' feet are in varying degrees of equinus, adduction, and inversion with an accentuated fat pad. On first standing, the child will usually adopt a wide stance and the flexible feet are forced into a pronated and everted position - they look like flat feet. ' With growth and development all those apparently abnormal factors that contributed to the formation of the flat foot are slowly and relentlessly corrected. By the age of 10 or so the tarsal bones have ossified and hardened, the ligamentous laxity of early childhood has resolved, the neuromuscular system has developed a fine motor control, and the normal leg alignment now provides for a normal load distribution from above, which leads to the feet adopting a normal shape.

Morley confirmed this natural resolution in his study of the natural course of footprints in children aged between 2 and
$10 .^{2} \mathrm{He}$ found that $97 \%$ of feet in children aged 2 were flat but only $4 \%$ persisted at age 10 . Painless and mobile flat feet in an otherwise normal young child do not require any treatment. Orthoses will not alter the natural correction - though sometimes heel cups and even special shoes are required to reassure parents. Some flat feet do persist, and usually a family history will be obtainable. Treatment will make no difference in these cases either.

Sometimes a child will have mobile flat feet that are painful, either locally within the foot or more proximally in the calf. Both types of pain are usually associated with activity, with the cramp in the calf often appearing at night some hours after the activity. Heel cups and moulded inserts will help to relieve symptoms. Even if the feet are persistently painful this is rarely severe enough to warrant surgery.

Flat feet may sometimes be secondary to a congenital or acquired condition that affects one or more of the main constituents of the normally functioning foot. When examining the foot, therefore, as well as looking for local abnormalities the clinician should be alert to changes in the shape or form of the foot that may point to disorders elsewhere. Many of the problems affecting the foot are difficult to diagnose at birth, but the abnormalities become apparent when the child starts to walk and deformity usually becomes more apparent with growth. By contrast, skeletal dysplasias or acquired problems such as cerebral palsy or meningomyelocoele can and should be diagnosed at birth. In such cases the foot should be looked at in the context of the overall management of the particular 